BMJ Open

Diabetes

Research

\& Care

\title{
High-dose insulin infusion in patients with COVID-19
}

\author{
Brandon Del Carpio (D , ${ }^{1}$ Joseph Trang, ${ }^{2}$ Megan Vallejo, ${ }^{2}$ Michael Nimeh, ${ }^{2}$ \\ Jinjoo Lee, ${ }^{2}$ Kelly Rafferty, ${ }^{3}$ Jordan Messler ${ }^{4}$
}

To cite: Del Carpio B, Trang J, Vallejo M, et al. High-dose insulin infusion in patients with COVID-19. BMJ Open Diab Res Care 2021;9:e002415. doi:10.1136/ bmjdrc-2021-002415

Received 3 June 2021 Accepted 19 0ctober 2021
Check for updates

\section{(C) Author(s) (or their} employer(s)) 2021. Re-use permitted under CC BY-NC. No commercial re-use. See rights and permissions. Published by BMJ.

${ }^{1}$ Pharmacy, AdventHealth Orlando, Orlando, Florida, USA ${ }^{2}$ Pharmacy, AdventHealth East Orlando, Orlando, Florida, USA ${ }^{3}$ Pharmacy, AdventHealth Central Florida, Orlando, Florida, USA

${ }^{4}$ Chief Medical Officer, Glytec, Waltham, Massachusetts, USA

Correspondence to Dr Brandon Del Carpio; brandon.delcarpio@ adventhealth.com
To the editor,

The SARS-CoV-2, which causes COVID19 , has resulted in over 100 million cases of infection and more than 2 million deaths globally, as of February 2021. Diabetes and uncontrolled hyperglycemia are risk factors for poor outcomes in patients with COVID-19 including increased risk of severe illness or death. ${ }^{1}$ One observational study described glycemic and clinical outcomes in 1122 patients with and without diabetes and/or acute uncontrolled hyperglycemia in 88 US hospitals. Among 570 patients who expired or were discharged, the mortality rate was $28.8 \%$ in 184 patients with diabetes and/or uncontrolled hyperglycemia, compared with $6.2 \%$ of 386 patients without diabetes or hyperglycemia $(p<0.001){ }^{2}$

This promoted a review of patients positive for COVID-19 requiring $\geq 100$ units/ hour of continuous intravenous insulin infusion (CIVII) admitted to our institution, a 1368-bed comprehensive quaternary care mixed academic/community referral center between 1 March and 30 April 2020. When reviewing patients, data collected included age, gender, weight, body mass index (BMI), medical history, and home diabetic medications. Additionally, intensive care unit (ICU) and hospital length of stay (LOS), inpatient mortality, and COVID-19 treatment regimens were collected. From the institution's computerized algorithm software, data collected included: CIVII rates, blood glucose (BG), steroid use, additional insulin given outside of algorithm and transitioning to basal/bolus regimens. Table 1 summarizes some of the main clinical characteristics and outcomes for each patient.

Of the 4 patients reviewed, $3(75 \%)$ were women, ages ranged from 36 to 72 , and all had a past medical history including diabetes
Table 1 Main clinical characteristics and outcome of our patients

\begin{tabular}{|c|c|c|c|c|c|c|c|c|c|c|c|c|}
\hline Patient & $\begin{array}{l}\text { Medical } \\
\text { history }\end{array}$ & $\begin{array}{l}\text { BMI } \\
\left(\mathrm{kg} / \mathrm{m}^{2}\right)\end{array}$ & A1C (\%) & $\begin{array}{l}\text { Insulin } \\
\text { naïve }\end{array}$ & $\begin{array}{l}\text { BG at } \\
\text { CIVII } \\
\text { initiation } \\
\text { (mg/dL) }\end{array}$ & $\begin{array}{l}\text { Average } \\
\text { BG on } \\
\text { CIVII } \\
\text { (mg/dL) }\end{array}$ & $\begin{array}{l}\text { Duration } \\
\text { on CIVII } \\
\text { (hours) }\end{array}$ & $\begin{array}{l}\text { Average } \\
\text { insulin } \\
\text { drip } \\
\text { rate } \\
\text { (units/ } \\
\text { hour) }\end{array}$ & $\begin{array}{l}\text { Highest } \\
\text { insulin } \\
\text { drip } \\
\text { rate } \\
\text { (units/ } \\
\text { hour) }\end{array}$ & $\begin{array}{l}\text { Steroid } \\
\text { use } \\
\text { during } \\
\text { CIVII }\end{array}$ & $\begin{array}{l}\text { Initial } \\
\text { regimen } \\
\text { after CIVII } \\
\text { D/C }\end{array}$ & Death \\
\hline 1 & $\begin{array}{l}\text { Type } 2 \\
\text { diabetes, } \\
\text { HTN, } \\
\text { obesity }\end{array}$ & 37.8 & 8.3 & Yes & 496 & 179 & 133 & 170 & 500 & Yes & $\begin{array}{l}\text { Insulin } \\
\text { glargine } \\
175 \text { units } \\
\text { two times } \\
\text { per day, } \\
\text { HDSS }\end{array}$ & Yes \\
\hline 2 & $\begin{array}{l}\text { Type } 2 \\
\text { diabetes, } \\
\text { CAD, } \\
\text { HTN, } \\
\text { HLD, } \\
\text { obesity }\end{array}$ & 40.3 & 7 & No & 352 & 199 & 79 & 182 & 500 & Yes & $\begin{array}{l}\text { Insulin } \\
\text { glargine } \\
175 \text { units } \\
\text { two times } \\
\text { per day, } \\
\text { HDSS }\end{array}$ & Yes \\
\hline 3 & $\begin{array}{l}\text { Type } 2 \\
\text { diabetes, } \\
\text { HTN, } \\
\text { obesity }\end{array}$ & 33.8 & 11.4 & Yes & 326 & 162 & $448^{*}$ & 21 & 100 & No & $\begin{array}{l}\text { Insulin } \\
\text { glargine } 80 \\
\text { units two } \\
\text { times per } \\
\text { day, HDSS }\end{array}$ & No \\
\hline 4 & $\begin{array}{l}\text { Type } 2 \\
\text { diabetes, } \\
\text { HLD, } \\
\text { obesity }\end{array}$ & 34.8 & 9.8 & Yes & 390 & 177 & 207 & 29 & 100 & Yes & $\mathrm{N} / \mathrm{A}$ & Yes \\
\hline
\end{tabular}

*The duration on CIVII for patient 3 is represented as the total hours of two separate initiations during the same hospital stay.

BG, blood glucose; BMI, body mass index; CAD, coronary artery disease; CIVII, continuous intravenous insulin infusion; D/C, discontinued; HDSS, high-dose sliding scale; HLD, hyperlipidemia; HTN, hypertension; N/A, not available. 
(defined as an $\mathrm{A} 1 \mathrm{C} \geq 6.5 \%$ ) and obesity (defined as a $\mathrm{BMI}>30 \mathrm{~kg} / \mathrm{m}^{2}$ ). Mean A1C was $9.1 \% \pm 1.6 \%$ and mean BG was $264.8 \pm 126.5 \mathrm{mg} / \mathrm{dL}$ on admission. All 4 patients were mechanically intubated prior to initiation of CIVII and enteral feeding was provided for all patients while on insulin infusion. Prior to CIVII initiation, the mean BG level was $391 \pm 64.8$ and median time to initiation was 2.5 days with an average of $201 \pm 144.7$ hours on CIVII at an average insulin drip rate of $97.6 \pm 78.7$ units. Out of the 4 patients, 2 required an insulin rate of 500 units/hour for a time and three died while still in the hospital. The mean ICU LOS was $15.9 \pm 11.5$ days and mean hospital LOS was $18.2 \pm 14.8$ days. Various treatment regimens were used including azithromycin, hydroxychloroquine, tocilizumab, sarilumab and corticosteroids to treat COVID-19 related disease but no one had received the same therapy as treatment guidelines were not established at the time of study.

The cause of hyperglycemia in patients with COVID-19 is multifactorial. It is suggested that the SARS-CoV-2 infection increases the expression of ACE2 in the pancreas. This increased expression, coupled with viral glycosylation, allows for viral uptake into the beta cells of pancreatic islets. SARS-CoV-2 can induce the destruction of these pancreatic cells, predisposing non-insulindependent patients with diabetes to induction of insulin autoimmune syndrome, resulting in impaired insulin production and increased insulin resistance. ${ }^{3}$ As BG increases, the more readily glycosylation occurs leading to increased ability of SARS-CoV-2 to invade the tissue and increase the risk of hyperglycemia. Additionally, significantly elevated cytokine levels may lead to impairments in pancreatic $\beta$-cell function and apoptosis and consequently decreased insulin production. ${ }^{4}$ Other complicating factors included stress, renal failure, use of corticosteroids, or vasopressor use leading to hyperglycemia and insulin resistance. ${ }^{56}$ CIVII programs have been shown to be an effective and safe tool for glycemic control in the hospital setting. ${ }^{78}$ Glucose control is an important factor in improving outcomes for patients with COVID-19 exhibiting higher than normal insulin requirements. This case series highlights that these patients can have high mortality rates and additional clinical attention may be warranted. Excursions from the normal care of these patients may be required to gain euglycemia, including, but not limited to, administration of higher insulin concentrations. Based on this review, the purpose of this letter is to draw further attention to the need for further studies evaluating patients positive for COVID-19 requiring $\geq 100$ units/hour of insulin and its impact on COVID-19 treatment outcomes.

Contributors JT, MV, MN, and JL collected the data and wrote the manuscript. BDC researched the data and wrote the manuscript. KR reviewed/edited the manuscript. JM conceptualized the design of work and reviewed/edited the manuscript.

Funding The authors have not declared a specific grant for this research from any funding agency in the public, commercial or not-for-profit sectors.

Competing interests None declared.

Patient consent for publication Not applicable.

Provenance and peer review Not commissioned; internally peer reviewed.

Open access This is an open access article distributed in accordance with the Creative Commons Attribution Non Commercial (CC BY-NC 4.0) license, which permits others to distribute, remix, adapt, build upon this work non-commercially, and license their derivative works on different terms, provided the original work is properly cited, appropriate credit is given, any changes made indicated, and the use is non-commercial. See: http://creativecommons.org/licenses/by-nc/4.0/.

ORCID iD

Brandon Del Carpio http://orcid.org/0000-0003-1963-8170

\section{REFERENCES}

1 Zhou F, Yu T, Du R, et al. Clinical course and risk factors for mortality of adult inpatients with COVID-19 in Wuhan, China: a retrospective cohort study. Lancet 2020;395:1054-62.

2 Bode B, Garrett V, Messler J, et al. Glycemic characteristics and clinical outcomes of COVID-19 patients hospitalized in the United States. J Diabetes Sci Technol 2020;14:813-21.

3 Omotosho YB, Ying GW, Stolar M, et al. COVID-19-Induced diabetic ketoacidosis in an adult with latent autoimmune diabetes. Cureus 2021;13:e12690.

4 Gupta A, Madhavan MV, Sehgal K, et al. Extrapulmonary manifestations of COVID-19. Nat Med 2020;26:1017-32.

5 Ceriello A, Zarich SW, Testa R. Lowering glucose to prevent adverse cardiovascular outcomes in a critical care setting. J Am Coll Cardiol 2009;53:S9-13.

6 Brufsky A, Hyperglycemia BA. Hyperglycemia, hydroxychloroquine, and the COVID-19 pandemic. J Med Virol 2020;92:770-5.

7 Newton CA, Smiley D, Bode BW, et al. A comparison study of continuous insulin infusion protocols in the medical intensive care unit: computer-guided vs. standard column-based algorithms. J Hosp Med 2010;5:432-7.

8 Yamashita S, Ng E, Brommecker F, et al. Implementation of the glucommander method of adjusting insulin infusions in critically ill patients. Can J Hosp Pharm 2011;64:333-9. 